\author{
St udia Philosophic a \\ Wr a t i s l a vi e n s i a \\ vol. XVI, fasc. 1 (2021) \\ https://doi.org/10.19195/1895-8001.16.1.7
}

\author{
ANTONI PŁOSZCZYNIEC \\ ORCID: 0000-0002-9111-9773 \\ IFiS UP w Krakowie
}

\title{
Rola ascetyzmu w antropologii filozoficznej Henryka Elzenberga*
}

\section{The role of asceticism in Henryk Elzenberg's philosophical anthropology}

\begin{abstract}
The aim of this article is the reconstruction, analysis and presentation of Henryk Elzenberg's philosophy of the human being, with particular emphasis on his concept of asceticism. Elzenberg's philosophical anthropology is based on the pessimistic evaluation of reality, which itself is founded on the negative evaluation of human nature. Human nature is corrupt because of the primary will of humanity, which is selfish and self-seeking and which strives only for utilitarian values. The overcoming of pessimism is possible by the transformation of self-seeking will, and asceticism is a remedy which enables human beings to see and realise true, perfectionist values. Asceticism can overcome basic instincts, which pull human nature down to the animal-like state of being. In Elzenberg's philosophical anthropology, asceticism creates culture and culture grants humanity to humans, which is a trope similar to the ancient conception of paideia.
\end{abstract}

Keywords: asceticism, values; self-overcoming, philosophy of culture, anthropological philosophy, pessimism

\footnotetext{
* Artykuł zrealizowano w ramach grantu pt. „Rola ascetyzmu w antropologii filozoficznej Henryka Elzenberga", nr 0420/2480/17 (wewnętrzny projekt badawczy WNS UWr).
} 


\section{Wstęp}

Zadaniem niniejszego tekstu jest rekonstrukcja fundamentalnych założeń Elzenbergowskiej filozofii człowieka. Analiza materiałów — w szczególności niepublikowanych rękopisów znanych jako Materiały Henryka Elzenberga w Archiwum Polskiej Akademii Nauk ${ }^{1}$ — wskazuje, iż filozoficzny namysł autora Kłopotu z istnieniem nad człowiekiem jako takim i jego naturą jest istotnie związany z jego koncepcja ascezy.

Teza niniejszej pracy głosi, że Elzenbergowska antropologia filozoficzna opiera się na jego koncepcji ascezy i jest przez nią uwarunkowana. W świetle antropologii autora Prób kontaktu człowiek jest istotą zdolną do samoprzezwyciężania oraz jest istotą, która powinna przezwyciężać siebie samą.

W artykule posłużono się metodą rekonstrukcyjną oraz analizą językową i analizą pojęciową. Podział pracy jest następujący. Najbliższy paragraf opisuje istotę Elzenbergowskiego rozumienia ascezy. Kolejny, trzeci paragraf przedstawia ogólne rozumienie natury ludzkiej przyjmowane przez polskiego aksjologa, a paragraf czwarty analizuje Elzenbergowski pesymizm, który stanowi koncepcyjny kontekst niezbędny dla zrozumienia antropologii filozoficznej autora Kłopotu z istnieniem. Piąty paragraf rozważa Elzenbergowską etykę przez pryzmat przezwyciężania pesymizmu antropologicznego, a szósty - rolę, jaką odgrywa tworzenie kultury w przezwyciężaniu pesymizmu oraz kulturotwórczą funkcję ascezy. Całość zamknie podsumowanie.

\section{Elzenbergowska koncepcja ascezy}

Autor Prób kontaktu zauważył, iż „,[w]alka z żądzą jest cechą większości systemów etycznych”2. „Wyrzeczeniowy” charakter etyki zależy od występowania w nim nakazu wyrzeczenia (niezależnie od tego, czy wyrzeczenie stanowi wartość pochodną czy ostateczną) oraz od swoistego charakteru wyrzeczenia uwarunkowanego przez jakiś znaczący stopień „doniosłości przedmiotów, których wyrzeczenie się jest nakazane, a przy nie dość wielkiej doniosłości także pewna powszechność nakazu”’3. W tym świetle opanowanie zdolności samoprzemagania jest kluczowe: „Najpraktyczniej zaczacc od wyrzeczenia, bo tak czy tak na nim skończyć wypadnie"*

Pierwotnie Elzenberg poświęcał uwagę nie ascezie jako takiej (jeszcze w 1919 roku ascezę rozumiał jako ,praktykowanie poszczególnych wyrzeczeń”牰, lecz wyrzeczeniu. Polski filozof odróżniał wyrzeczenie zewnętrzne i wewnętrzne. W paragrafie

\footnotetext{
1 Adres bibliograficzny Materiałów Henryka Elzenberga oznaczono skrótowcem MHE. Po cyfrach wskazujących sygnaturę zbioru (III-181) znajduje się numer teczki, w której znajduje się cytowany fragment oraz numer karty (w rękopisach nie ma podziału na strony). Nieistotne dla rozważań fragmenty oznaczono znakiem ,[...]”. W artykule zachowano oryginalne — i niekiedy archaiczne — zasady ortograficzne i gramatyczne rękopisów.

${ }^{2}$ H. Elzenberg, Walka moralistów z żądza, [w:] MHE III-181-36, k. 1.

3 H. Elzenberg, Etyka wyrzeczenia. Czym jest i jak bywa uzasadniania?, [w:] idem, Pisma etyczne, oprac. L. Hostyński, Lublin 2001, s. 4.

${ }^{4}$ H. Elzenberg, Kłopot z istnieniem. Aforyzmy w porządku czasu, Toruń 2002, s. 143 (16 IX 1919).

${ }^{5}$ H. Elzenberg, Etyka wyrzeczenia, [w:] idem, Pisma etyczne, s. 158.
} 
zatytułowanym „Pojęcie wyrzeczenia: wyrzeczenie zewnętrzne” toruński filozof przedstawia następującą definicję. Wyrzec się ,»[...] jest to wyzbyć się dobrowolnie rzeczy przez nas pożądanej, o ile ją posiadamy, albo, również dobrowolnie, przestać (ewentualnie: nie zaczynać) do niej dążyć, o ile jej nie posiadamy, ale mamy pewność albo szansę jej osiągnięcia«. W skróceniu: »wyzbyć się dobrowolnie rzeczy pożądanej lub szans jej osiągnięcia «"6. W takim razie wyrzeczenie zewnętrzne jest postępowaniem kładącym kres posiadaniu lub dążeniu.

W odróżnieniu od wyrzeczenia zewnętrznego, które zmienia jakiś stan rzeczy w świecie „na zewnątrz” ludzkiej psychiki, wyrzeczenie wewnętrzne „polega na pewnej zmianie zachodzącej w życiu psychicznym"7. Wyrzeczenie wewnętrzne polega na zniweczeniu pożądania jakiejś rzeczy, wykorzenieniu żądzy, kładzie kres nie posiadaniu rzeczy pożądanej ani dążeniu do niej, lecz samej żądzy.

Elzenberg podkreśla, że możliwe jest dokonywanie zarówno wyrzeczenia czysto zewnętrznego (na przykład można wyrzec się luksusów, nie przestając ich pożądać), jak i czysto wewnętrznego (można nie przywiązywać się do luksusów, nie pozbywając się ich). Niemniej (choć nie ma w tym konieczności ani praktycznej, ani logicznej) oba wyrzeczenia często są nakazywane wspólnie, ponieważ dokonywanie wyrzeczeń tylko jednego rodzaju miewa ujemne aspekty, którym zapobiega dodatkowe spełnienie wyrzeczenia drugiego rodzaju. Przykładowo, ten, kto wyrzekł się swojej kolekcji znaczków pocztowych i przekazał je innym, nie przestając owych znaczków pożądać, naraża się na cierpienie, któremu kres przyniosłoby wyrzeczenie się znaczków ,w sercu swoim”.

Elzenberg formułuje pojęcie wyrzeczenia w ogóle, obejmujące odmianę zewnętrzną i wewnętrzną. Tak ujęte wyrzeczenie jest to ,»[z]achowanie się wobec rzeczy dotychczas pożądanej inne niż to, które by nastąpiło, gdyby o nim rozstrzygało nasze dotychczasowe pożądanie« — czyli w skróceniu: »oparcie się swemu pożądaniu «, »przezwyciężenie pożądania «"

Ogólnie rozumiane wyrzeczenie stanowi gatunek szerszego pojęcia: samoprzezwyciężenia. Samoprzezwyciężenie ma dwie formy: negatywną i pozytywną. Wyrzeczenie, czyli przezwyciężenie pożądania, Elzenberg nazywa „samoprzezwyciężeniem negatywnym”. „Negatywny” charakter wyrzeczenia polega na tym, że wyzwalamy siebie od rzeczy pożądanej, dążenia do niej, posiadania jej lub samej żądzy. Samoprzezwyciężenie pozytywne polega nie na przezwyciężeniu pożądania, lecz na przezwyciężaniu jego braku. Ten, kto dokonuje samoprzezwyciężenia pozytywnego, zachowuje się tak, jakby pożądał, choć nie pożąda, stąd istotą samoprzezwyciężenia pozytywnego jest zmuszanie siebie do działania mimo braku żądzy. Jest to przemaganie się do określonego postępowania. „Wspólna definicja obu form samoprzezwyciężenia mówiłaby ogólnie o zachowaniu się innym niż to, które by wynikało z naszego dotychczasowego »stosunku pożądaniowego« (to znaczy pożądania lub jego braku) do danej rzeczy"9.

\footnotetext{
6 Ibidem, s. 5.

7 Ibidem, s. 6.

8 Ibidem, s. 20.

9 Ibidem, s. 21.
} 
Pojęcie samoprzezwyciężenia odgrywa kluczową rolę w późniejszej definicji ascezy. W rękopisie pt. O ascetycznym podłożu wszelkiej kultury Elzenberg przeczy, by asceza była „praktykowaniem poszczególnych wyrzeczeń”. Pojęcie ascezy „nie pokrywa się z pojęciem »wyrzeczenia « [...]; ascezę [...] zdefiniuje się raczej przez pojęcie samoprzezwyciężania. (Każde wyrzeczenie wymaga samoprzezwyciężenia, ale nie każde samoprzezwyciężenie jest wyrzeczeniem; można przezwyciężać się, zwalczając w sobie skłonności nie będące bynajmniej pożądaniami [...] jak kiedy na przykład ktoś przezwycięża wrodzoną skłonność do gniewu"10. Wedle pierwszego określenia z rękopisu asceza jest to ,systematyczna, celowa praktyka samoprzezwy-

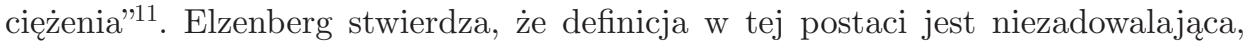
gdyż tymi samymi słowami można określić dyscyplinę moralną, a przecież asceza jest od niej „czymś większym” (,większym” jako coś bardziej określonego pod względem treści oraz jako coś wartościowszego).

Autor Prób kontaktu formułuje dodatkowe warunki definicji ascezy pozwalające odróżnić ją od „zwykłej” dyscypliny moralnej. Pierwszy warunek stanowi „zwalczanie w sobie skłonności ogólnoludzkich (»ludzkiej natury«) — a nie indywidualnych odchyleń"12. O specyficznym charakterze ascezy decyduje nie przezwyciężanie względnie nietypowych i rzadkich skłonności jednostek (jak patologiczna skłonność do zmyśleń barona Münchhausena), lecz skłonności wspólnych ogółowi ludzi, jak skłonność do kierowania się własnym interesem. Drugi warunek głosi, że asceza w odróżnieniu od „zwykłej” dyscypliny moralnej posiada „wyższy stopień trudności i wysiłku, - i ambicji (zamierzonych zmian w sobie)"13. Na czym polega ,wyższy stopień trudności i ambicji”? Wedle Elzenberga natura ludzka ma dwa wymiary: biologiczny i duchowy. Sfera biologiczna stanowi fundament bytowy tego, co duchowe, bo istnienie sfery duchowej jest uwarunkowane przez czynniki biologiczne. Poza przewaga ontyczną istnieje jeszcze przewaga dynamiczna: motywacja oparta na impulsach biologicznych jest w zasadzie silniejsza od motywacji czysto duchowej. Stąd wysiłek ascetyczny jest większy niż w przypadku ,zwykłej” dyscypliny moralnej, bowiem asceza usiłuje przezwyciężyć silniejszą część natury ludzkiej. Według trzeciego warunku definicyjnego ascezie muszą towarzyszyć „,motywy nie z chęci dociągnięcia się i dostosowania do otoczenia społecznego i jego wymagań [...]; tylko bardziej indywidualne, ponadspołeczne, »idealne «"14. Ascezie zasadniczo towarzyszy motywacja o charakterze mniej lub bardziej aksjologicznym (chcenie spełnienia powinnego stanu rzeczy dlatego, że jest powinny), nie zaś motywacja związana $\mathrm{z}$ wartościami w znaczeniu utylitarnym ${ }^{15}$ (chęć zyskania korzyści, uniknięcia przykrości, zaspokojenia pożądania itp.).

10 H. Elzenberg, O ascetycznym podłożu wszelkiej kultury, [w:] MHE III-181-61, k. 6.

11 Ibidem, k. 1.

12 Ibidem.

13 Ibidem, k. 2.

14 Ibidem.

15 W tej pracy używa się zwrotu „wartość w znaczeniu utylitarnym” zamiast „wartość utylitarna”, ponieważ według Elzenberga wartością sensu stricto jest wartość perfekcyjna. Zob. H. Elzenberg, Pojęcie wartości i powinności. Tekst żemłosławski, [w:] idem, Pisma aksjologiczne, oprac. L. Hostyński, A. Lorczyk, A. Nogal, Lublin 2002, s. 131-132. 
Na kartach O ascetycznym podłożu wszelkiej kultury znajduje się jeszcze jedna ogólna definicja ascezy: „samoprzezwyciężenie (systematyczna celowa praktyka (— z celem samowychowawczym lub samokształtujaccym)? )"16. Polski aksjolog wyraża wahanie, czy ascezę należy definiować w kategoriach celów autopedagogicznych. Elzenberg nie rozwija tego wątku, ale z uwagi na podkreślanie sam wychowawczej roli wyrzeczenia ${ }^{17}$ oraz z powodu kulturotwórczej funkcji ascezy, wydaje się słusznym uznać, iż zamiar ukształtowania siebie samego jest czwartym warunkiem definicyjnym ascezy.

\section{Elzenbergowskie ujęcie natury ludzkiej}

Natura ludzka wedle Elzenberga ma dualistyczne rysy. Człowiek jest uczestnikiem dwóch przeciwstawnych sobie sfer (resp. wymiarów): biologicznej i duchowej. Nie jest to dualizm substancji (R. Descartes) ani dualizm zasad metafizycznych (M. Scheler), lecz dualizm natury ludzkiej, która jednocześnie uczestniczy w sferze biologicznej oraz ponad-biologicznej. Jak pisze Agnieszka Nogal, antropologia filozoficzna wedle ujęcia Elzenberga ,,jest opisem obu sfer, ich przenikania i wzajemnej zależności"18. Ze względu na swój dualistyczny charakter i szczególną uwagę poświęconą duchowej stronie natury ludzkiej, antropologię filozoficzną Elzenberga należy określić — za Schradem — jako antynaturalistyczną ${ }^{19}$.

Tym, co dzieli oba wymiary natury ludzkiej, jest odmienny charakter relacji podmiotu wobec świata, a w szczególności odmienny sposób wartościowania. Sferze biologicznej właściwa jest podmiotowa perspektywa oglądu świata, a sferze ponadbiologicznej - przedmiotowa. Na związek sfery podmiotowej z tym, co w człowieku biologiczne, wskazuje fragment z Walki moralistów z żądza, w której mowa o podmiocie biologicznym, ,który je, pije, i świat by na swoje potrzeby obrócił"20. Istotne znaczenie ma wyrażenie ,na swoje [...] obrócił”, ponieważ konotuje autocentryczny „nawrót ku sobie”, który w Kłopocie z istnieniem i w innych zapiskach był przeciwstawiany temu, co duchowe ${ }^{21}$.

Właściwe perspektywie podmiotowej jest to, że wszelka rzecz poznawana lub oceniana jest ujmowana w odniesieniu do (jakiegoś) podmiotu. Podmiotowy ogląd rzeczywistości może mieć charakter egoistyczny lub altruistyczny (na przykład gdy ocenia się $X$ jako dobre, bo jest dobre dla innych), ale za każdym razem wartość jest zrelatywizowana do jakiegoś podmiotu lub podmiotów. Najdobitniej perspektywę podmiotową wyraża autocentryzm. Autocentryzm jest to pewien sposób ujmowania rzeczywistości, zgodnie z którym przedmiot $X$ jest przedstawiany przez

16 H. Elzenberg, O ascetycznym podtożu wszelkiej kultury, k. 11.

17 H. Elzenberg, Etyka wyrzeczenia. Czym jest i jak bywa uzasadniana, s. 9.

18 A. Nogal-Ponikiewska, Watki antropologiczne w filozofii Henryka Elzenberga. Rekonstrukcja $i$ historyczno-filozoficzna analiza porównawcza, Warszawa 1998 (nieopublikowana praca doktorska), s. 6. Dziękuję Pani Profesor za możliwość skorzystania z tekstu.

19 U. Schrade, Natura ludzka a wartości, „Archiwum Historii Filozofii i Myśli Społecznej” 34 (1989), s. 82-83.

20 H. Elzenberg, Walka moralistów z żądza, k. 7.

21 H. Elzenberg, Kłopot z istnieniem, s. 60 (bez daty 1910). 
podmiot autocentryczny jako taki a taki, ponieważ w taki a taki sposób oddziałuje na podmiot. Autocentryczną miarę oceny wszystkich rzeczy stanowi sposób, w jaki one oddziałuja na podmiot. Autocentryczny charakter ma na przykład ocena zmiany przepisów podatkowych jako ,słusznych i sprawiedliwych", właśnie dlatego, że dzięki nim osiągnęło się korzyść finansową.

W ramach perspektywy przedmiotowej rzeczy są ujmowane nie w odniesieniu do podmiotu, lecz w obrębie samych siebie, niejako ,autonomicznie”. Związana z perspektywą przedmiotową sfera ponad-biologiczna „kieruje się ku temu, co niezależne od podmiotu, jej normą jest ogląd przedmiotowy"22. Różnica między sferą podmiotową i przedmiotową jest analogiczna w stosunku do różnicy między relatywistyczno-subiektywistycznym ujęciem świata a obiektywistycznym. W perspektywie przedmiotowej możliwe jest ujmowanie przedmiotu w izolacji: można ująć $X$ jako $X$, ująć $X \mathrm{w}$ jego naturze, abstrahując od możliwych stosunków łączących ów $X$ z podmiotem odnoszącym się do $X$ lub z innymi podmiotami. Z kolei w perspektywie podmiotowej ogląd przedmiotowy jest nieobecny lub traktowany jako nieistotny, a nawet jako wręcz bezsensowny (na przykład w myśl relatywizmu Protagorasa).

Sferze biologiczno-podmiotowej właściwe są wartości w znaczeniu utylitarnym, a sferze duchowo-przedmiotowej — wartości perfekcyjne. Należy przypomnieć, że według Elzenberga wartościowe w znaczeniu utylitarnym jest wszystko to, co związane z zaspokojeniem pożądania, zaspokojeniem potrzeby, dostarczaniem przyjemności lub „Zwiększaniem istnienia”. Z kolei wartościowe perfekcyjnie jest to, co jest takie, jakie powinno być - „powinno” w ogóle, w sensie ontycznym (Soseinsollen).

Wartości w znaczeniu utylitarnym są właściwe perspektywie podmiotowej. Wartość w znaczeniu utylitarnym ,,jest, z samej istoty swej, (cechą) względną; jest to zawsze wartość dla kogoś (ewentualnie czegoś) i ta sama rzecz może być wartościowa ze względu na jedną osobę, która jej pożąda, potrzebuje lub w niej znajduje przyjemność, a nie być nią dla drugiej osoby"23. Wartości w znaczeniu utylitarnym mają charakter podmiotowy, ponieważ z istoty są wartościami dla kogoś, o ich wartościowości stanowi zdolność zaspokojenia potrzeb i pragnień jakiegoś podmiotu lub podmiotów, względnie odpowiedniość między naturą rzeczy ocenianej a naturą czegoś innego (Elzenberg wskazał przykład władzy dla osób ambitnych). Wartość w znaczeniu utylitarnym jest każdorazowo zrelatywizowana do czegoś, podobnie jak rzeczy oglądane w ramach perspektywy podmiotowej są relatywizowane do jakiegoś podmiotu. Z kolei wartości perfekcyjne mają charakter przedmiotowy i są swoiste sferze przedmiotowej, bowiem to, co jest wartościowe perfekcyjnie, jest wartościowe par excellence, bezwzględnie, a nie dla kogoś. Elzenberg jako przykład wskazał zdanie „Duch jest więcej wart niż materia”, które stwierdza pewną bezwzględną wartość ducha i jego wyższość nad materią, nie zaś, że ktoś bardziej pragnie ducha niż materii lub że materia jest mniej przyjemna niż duch ${ }^{24}$.

Wartości w znaczeniu utylitarnym są związane z biologiczną stroną natury ludzkiej, perfekcyjne zaś - z duchową. Elzenberg uważa, że najsilniejszy instynkt

22 A. Nogal-Ponikiewska, Watki antropologiczne w filozofii Henryka Elzenberga, s. 7.

23 H. Elzenberg, Pojęcie wartości i powinności, s. 126.

24 Ibidem, s. 127-128. 
w człowieku to instynkt samozachowawczy ${ }^{25}$, a drugi po nim jest instynkt płciowy. Uznanie, że zachowanie własnego życia stanowi naczelne dążenie każdej istoty żywej — w tym człowieka — „umożliwia całkowicie obiektywne ustalenie warunków koniecznych, a łącznie wystarczających do zachowania życia, czyli potrzeb"26. Jeżeli dalej, za Schradem, zdefiniujemy pragnienie jako ,aspirowany poziom realizacji danej potrzeby"27 oraz powiążemy przyjemność i „zwiększenie istnienia” z zakresem i stopniem zaspokojenia pragnień i potrzeb, okazuje się, że wartości w znaczeniu utylitarnym wyrażają biologiczny wymiar natury ludzkiej.

Kultura, twór duchowy par excellence i summun bonum w filozofii autora Wartości $i$ człowieka ${ }^{28}$, „nie rodzi się z potrzeb. Właśnie działanie dla czego innego niż dla zaspokojenia jakiejkolwiek potrzeby jest źródłem, sensem i istotą kultury"29. Duch przeciwstawia się temu, co autocentryczne. Elzenberg stwierdził: „Przez »ducha« rozumiem sumę tych dążeń i popędów człowieka, które za cel biorą nie jego samego — czyli dokładniej: nie jego własny byt albo korzyść — i nie byt ani korzyść innych też ludzi, ale stany rzeczy cenne w nim i poza nim; dążenia i popędy, które do niego nie »wracają«, nie są ani w znaczeniu jednostkowym, ani w znaczeniu gatunkowym, autocentryczne. Ogólnikowo: sumę popędów bezinteresownych"30. Człowiek jest zdolny do zajmowania bezinteresownej postawy, która jest możliwa dzięki immanentnej duchowi zdolności do uprzedmiatawiania tego, co poznawane. Owa zdolność wyraża istotę ducha: „duch to podmiot, quatenus sam siebie ujmuje jako przedmiot"31.

Wedle Elzenberga duchowy wymiar natury ludzkiej jest uwarunkowany biologicznie $^{32}$. To, co biologiczne w człowieku, jest bytowo pierwotniejsze względem ducha, którego istnienie jest ufundowane na tym, co biologiczne. Człowiek jest istotą, w której są obecne dwie sfery — biologiczna i ponad-biologiczna — różniące się szlachetnością i siłą. Sfera duchowa jest wyższa i słabsza, a biologiczna - silniejsza i niższa. Ów obraz natury ludzkiej odpowiada tezie Schelera, iż ,[w]yższe kategorie bytu i wartości są w rzeczy samej kategoriami słabszymi”33. To, co szczególnie wysokie (sfera ponad-biologiczna), musi walczyć przeciw czemuś silniejszemu i mniej szlachetnemu. Walka ducha przeciw naturze jest trudna, a zwycięstwo nigdy nie jest ostateczne, bowiem całkowita przemiana natury ludzkiej jest utopijna ${ }^{34}$.

25 H. Elzenberg, Ktopot z istnieniem, s. 90 (28 XII 1913).

26 U. Schrade, Natura ludzka a wartości, s. 74.

27 Ibidem, s. 77.

28 Hipoteza, że w filozofii Elzenberga kultura stanowi „najwyższe dobro” wydaje się dopuszczalna z uwagi na „kulturalizm” Elzenberga. Zob. H. Elzenberg, Nauka i barbarzyństwo, [w:] idem, Pisma aksjologiczne, s. 355-356.

29 H. Elzenberg, Kłopot z istnieniem, s. 60 (bez daty 1910).

30 Ibidem, s. 149 (bez daty 1919).

31 Ibidem, s. 46 (21 IV 1959).

${ }^{32}$ H. Elzenberg, O rzeczywistym wodzostwie (w zwiazku z dyskusja o Gandhim), [w:] MHE III-181-56, k. 75 .

33 M. Scheler, Stanowisko człowieka w kosmosie, tłum. A. Wegrzecki, [w:] idem, Pisma z antropologii filozoficznej i teorii wiedzy, tłum. S. Czerniak i A. Węgrzecki, Warszawa 1987, s. 115.

34 H. Elzenberg, O rzeczywistym wodzostwie, k. 75. 


\section{Pesymizm, człowiek, zło}

Filozofię Elzenberga można ująć jako próbę „przezwyciężenia pesymistycznej postawy wobec świata"35. Omówienie tej kwestii wymaga wyjaśnienia natury wartości ujemnej. Wedle Elzenberga przedmiot jest wartościowy dodatnio, gdy jest taki, jaki powinien być, jest natomiast wartościowy ujemnie, gdy jest taki, jaki powinien nie być. Jeżeli przedmiot $X$ jest dodatnio wartościowy wtedy i tylko wtedy, gdy faktycznie posiada cechę $c$ i gdy zarazem powinien posiadać $c$, to przedmiot $X$ jest wartościowy ujemnie, jeżeli posiada cechę $d$, która wyklucza posiadanie cechy $c$ przez $X$. Filozof zauważa, że wiedza o tym, co jest dodatnio wartościowe, implikuje wiedzę o tym, co jest wartościowe ujemnie. Załóżmy, że jest jakiś przedmiot $P$, o którym wiemy, że posiada cechę $q$ oraz powinien posiadać $q$. Zatem $q$ jest cechą dodatnio wartościotwórczą, czyli cechą nadającą danemu przedmiotowi wartość dodatnią. Jeżeli okaże się, że posiadanie przez $P$ cechy $r$ wyklucza posiadanie przez $P$ cechy $q$, to $r$ można nazwać cechą ujemnie wartościotwórczą. Jeżeli $P$ powinien posiadać $q$, to o ile posiadanie $r$ wyklucza posiadanie $q, P$ powinien nie posiadać $r$. Elzenberg zauważa, że stosunek odwrotny nie zachodzi: z sądu o cechach, których przedmiot powinien nie posiadać, nie wynika sąd, którą cechę powinien posiadać, o ile nie zachodzi dysjunkcja ,albo $q$, albo $r$ ". Przesłanką tego jest okoliczność, że ujemnie wartościotwórcza cecha $r$ może wykluczać się nie tylko z dodatnimi cechami, ale również z innymi ujemnie wartościotwórczymi cechami lub z cechami obojętnymi. Przykładowo, ,jeżeli cechą ujemnie wartościotwórczą jest trójkątność, to mogą nimi być [to jest cechami wykluczającymi się z trójkątnością - dop. A.P.] zarówno dodatnio wartościotwórcze okrągłości, jak i ujemnie wartościotwórcza kwadratowość; może nią być również — nie na tym przykładzie! — jakaś cecha po prostu obojętna"36.

Z rozważań Elzenberga nad pojęciem wartości ujemnej wynika, że wszelka wartość ujemna ma charakter pochodny. To znaczy, że część racji, dla której jakiś przedmiot jest wartościowy ujemnie, tkwi zawsze w wartości przedmiotu, ponieważ powinność nieposiadania cechy ujemnie wartościotwórczej $r$ przez przedmiot $X$ ostatecznie wynika z powinności posiadania jakiejś cechy dodatnio wartościotwórczej $q$ przez $X^{37}$.

Wróćmy do kwestii pesymizmu. W filozofii Elzenberga wyróżnia się rozmaite rodzaje pesymizmu. Na podstawie jego pism można wymienić pesymizm samotniczy, pesymizm antropologiczny, państwowy, społeczny, historiozoficzny i kosmiczny.

Pesymizm samotniczy dotyczy samotnej kondycji właściwej każdej jednostce ludzkiej. Źródło pesymizmu samotniczego tkwi w emocjonalnej izolacji każdego indywidualnego człowieka, związanej z tym, że nikt nie może przeżywać tego, co wartościowe w ten sam sposób co ja sam, gdyż wszelkie przeżycie jest pierwszoosobowe i niepodobna udzielić go innym. Wpływ na to ma okoliczność, że inni ludzie nie są skłonni do uznawania tych samych rzeczy za najcenniejsze. „Przeżycia, które dla otoczenia są niedostępne, tym samym nie mogą budzić sympatii. Ale jeśli

35 M. Tyl, Pesymizm, konserwatyzm, wartości. O filozofii Henryka Elzenberga, Katowice 2001, s. 9.

${ }^{36}$ H. Elzenberg, Wartość ujemna, [w:] idem, Pisma aksjologiczne, s. 175.

37 Ibidem, s. 174 . 
jej nie budzą nasze przeżycia najważniejsze, wychodzi na to, że poza kręgiem sympatii pozostaje to, co — w naszym pojęciu — jest dla nas najcenniejsze, rdzeń nasz istotny" 38 .

Pesymizm antropologiczny jest pesymizmem co do natury ludzkiej (resp. człowieka jako takiego). Natura ludzka jako taka ma charakter ujemnie wartościowy. Przesłanki owej oceny nie stanowi sam fakt, że człowiek nie jest taki, jaki powinien być (to bowiem może być skutkiem nie zepsucia, lecz słabości), lecz jego brak chęci by być takim, jakim powinien być: „człowiek (»na ogół«) nie aspiruje do żadnej z wartości, które stanowią rdzeń i trzon mojej aksjologii. Nie posiada dobrej woli. Z mojego punktu widzenia, człowiek jest zasadniczo i esencjonalnie istotą złej woli. Nie posiadajac aspiracyj ku dobru przechwala się tym, że ich nie posiada, a potępia tych, którzy by chcieli, by je posiadał. [...] Człowiek nie chce wartości, w nią nie wierzy, chce tylko siebie"39. Wedle Elzenberga zło właściwe naturze ludzkiej nie polega na dążeniu do popełniania zbrodni dla samej zbrodni — jeśli człowiek dopuszcza się zbrodni, to dlatego, że uważa, że jest dla niego korzystna, że zrobienie czegoś wbrew normom daje mu satysfakcję itp. W takim razie zło wpisane w naturę ludzką polega nie na dążeniu do stanu, który jest taki, jaki powinien nie być, dla niego samego, lecz na obojętności na to, czy to, co się czyni, jest zgodne z powinnością. Bogusław Wolniewicz przytacza niedatowaną notatkę Elzenberga:

\section{Nieistnienie radykalnego zła}

Com nieraz mówił, że nie ma szatańskości, że człowiek na skali dobra i zła nie może zejść poniżej punktu zero (nie jest to termometr ze stopniami minus), że wrogiem dobra jest natura (ów punkt zero właśnie), nie jakieś samodzielne, przeciwstawne mu zło — nie diabeł, tylko świnia. To nie znaczy, żeby nie było rzeczy złych, przeciwwartości, cechy zła: to wszystko istnieje; cecha zła tak samo jak cecha dobra; ale to znaczy, że człowiek nigdy nie dąży do zła jako zła, ale że czyni zło przez to, że idzie za swoim popędem naturalnym; - może czasem wiedzieć, że to zło i mimo to dążyć, ale nigdy dlatego, że to zło. „Natura” w człowieku, obojętna na kategorie dobra i zła, pcha go tu i tam — to do dobrego, to do złego, to do rzeczy obojętnych; i takie poddawanie się naturze, to jest punkt zero. - Można tylko przypadkowo mieć z natury więcej skłonności zmierzających ku złemu, albo ku dobremu, — ale nie ma na świecie woli skierowanej ku złu jako takiemu. Istnieje tylko wola popychana (czy ciągniona) przez naturę, i wola skierowana ku dobremu. Ale za to natura wchodzi w rolę jedynego czynnika pchającego ku złemu, jest jedyną siłą realizującą zło w świecie - i stąd front przeciw niej i jej pewne zepchnięcie w skali wartości ${ }^{40}$.

Rozważania nad złem natury ludzkiej są uwarunkowane tezami o charakterze wartości ujemnej. Nie ma woli diabelskiej, która chce zła dla samego zła, ponieważ wszelka wartość ujemna jest wartością pochodną. Jak napisał Wolniewicz, „natura ludzka jest obojętna na wartości perfekcyjne, ale nie jest im wroga; nie dba o nie, ale ich tė̇ szczególnie nie niszczy. Niszczy je tylko mimochodem"41. Dodać trzeba: niszczy przy okazji dbania o własny interes.

38 H. Elzenberg, Kłopot z istnieniem, s. 255 (5 IV 1936).

${ }^{39}$ H. Elzenberg, Sprawy zbiorowości ludzkiej a mój system myślowy, [w:] idem, Z filozofii kultury, Kraków 1991, s. 358.

${ }^{40}$ Cyt. za: B. Wolniewicz, Myśl Elzenberga, [w:] idem, Filozofia i wartości. Rozprawy i wypowiedzi z fragmentami pism Tadeusza Kotarbińskiego, Warszawa 1993, s. 92.

41 Ibidem, s. 94. 
Pesymizm państwowy wyraża ujemna ocena państwa jako takiego i jego możliwości. Wedle wczesnych poglądów Elzenberga, ukształtowanych jeszcze w drugim dziesięcioleciu XX wieku, wojna miała pełnić kulturotwórczą funkcję przez wywoływanie masowego zrywu męstwa i heroizmu, państwo zaś służyło prowadzeniu wojen. Po własnych doświadczeniach wojennych i obserwacjach funkcjonowania państwa i realnych warunków prowadzenia wojen filozof stwierdził, że państwo nie może stanowić „,szkoły bohaterstwa”42.

Przedmiotem pesymizmu społecznego jest społeczeństwo jako takie. Większe grupy ludzkie spontanicznie en masse kierują się do zła. „Społeczeństwo może w swej masie zawierać ludzi mądrych i dobrych: samo zawsze jest głupie i złe. Jest amoralne, egoistyczne, drapieżne, tyrańskie wobec swych członków; aspiracje ma niskie, wierzenia płaskie; jest nieskończenie gorsze od przeciętnie przyzwoitej jednostki"43. Wspólnoty ludzkie z reguły są zepsute i niemoralne.

Przedmiotem pesymizmu dziejowego (vel historiozoficznego) są dzieje ludzkie. Przesłanką ujemnej oceny dziejów jest to, że dzieje nie mają sensu i nie prowadzą do żadnego dodatnio wartościowego celu. Nie dążenie do złego, lecz brak jakiegokolwiek celowego ukształtowania dziejów (tym bardziej brak dążenia do dobrego celu) stanowi o ujemnej ocenie dziejów.

Ostatni rodzaj pesymizmu to pesymizm kosmiczny. Jego przedmiotem jest „,kosmos", to jest całokształt świata i porządku w nim panującego. Kosmos nie jest zły jako taki, lecz jest zły ze względu na jego indyferencję wobec tego, jak powinno być.

Źródłowym i najważniejszym rodzajem pesymizmu w filozofii jest Elzenberga pesymizm antropologiczny: „o człowieku nigdy nie można myśleć dosyć pesymistycznie" ${ }^{44}$. W niniejszym tekście stawia się hipotezę, że pozostałe rodzaje pesymizmu opierają się na pesymizmie antropologicznym, przez co pesymizm względem natury ludzkiej zasługuje na miano pesymizmu fundamentalnego w obrębie myśli Elzenberga, gdyż każdy pozostały rodzaj pesymizmu jest uwarunkowany przez pesymizm antropologiczny.

Uwarunkowanie pesymizmu samotniczego polega na tym, że źródła emocjonalnej izolacji tkwią we właściwościach natury ludzkiej. Ponieważ człowiekowi z natury zależy najbardziej na samym sobie, głównie interesują go jego przeżycia tego, co wartościowe, jego preferencje wartości i to, co on sam uważa za wartościowe. Samotnicza kondycja jednostki ludzkiej wyrażająca się w emocjonalnej izolacji jest lepiej zrozumiała w kontekście autocentryzmu, który relatywizuje przedmioty oceny z uwagi na sposób, w jaki one oddziałują na podmiot oceniający (te sama rzecz bowiem może różnie oddziaływać na różnych ludzi). Autocentryczne zwracanie się ku sobie samemu powoduje, że człowiek jest z gruntu niezainteresowany wspólnym przeżywaniem wartości.

\footnotetext{
${ }^{42}$ H. Elzenberg, Sprawy zbiorowości ludzkiej a mój system nerwowy, s. 356.

43 Ibidem, s. 357.

44 H. Elzenberg, Kłopot z istnieniem, s. 332, s. 301 (21 XII 1941).
} 
Jeżeli idzie o pesymizm kosmologiczny, H. Elzenberg pisze:

W gruncie rzeczy, gdy tak czasem mówię o świecie jako „złym”, mam na myśli nie kosmos, tylko świat społeczny, życie zbiorowe [...]. Mam wrażenie, że z pesymizmem u wielu ludzi tak bywa: nieświadome jakieś, przed samym sobą, maskowanie głównej przyczyny. Dlaczego? chyba dlatego, że wstyd jest do niej się przyznać. Rozpacz, gdy z powodu świata, nie upokarza; upokarza, gdy z powodu człowieka ${ }^{45}$.

W przypadku pesymizmu społecznego i dziejowego należy zauważyć, że ujemne cechy właściwe społeczeństwu w ogóle oraz ujemne cechy charakterystyczne dla dziejów opierają się na pewnych cechach natury ludzkiej:

W życiu wielkich grup i przejawach, nawet indywidualnych, dotykających tego życia (,zjawiska makrospołeczne") przewagę wpływów ma zło. Jednak takie sformułowanie, choć ograniczające pesymizm, nie całkiem wyjmuje zpod niego naturę ludzką, bo widocznie są w naturze ludzkiej jakieś właściwości, kt.[óre — dop. A.P.] do tego prowadzą, ( - są u podstaw tego zjawiska). — Chodziłoby więc nie o to poprostu, że w naturze ludzkiej zło przeważa, ogólnie biorąc, nad dobrem, ale że tkwią w niej jakieś własności ${ }^{46}$, kt.[óre — dop. A.P.] złu zapewniają przewagę na terenie makrospołecznym, a tym samym oddają w jego ręce władzę ${ }^{47}$.

Jakie właściwości Elzenberg ma na myśli? Po pierwsze, człowiek z natury jest interesowny, a społeczeństwo stanowi podmiot zbiorowy, który także jest interesowny. Gdy społeczeństwo demoralizuje jednostkę, często czyni to przez swoiste „przekupywanie” jej zaszczytami i honorami za działania w imię interesu społecznego: ,grupa społeczna [...] zazwyczaj ma swoje interesy, namiętności i t.d., często w imię tych właśnie interesów i namiętności wywiera nacisk na sąd jednostki, wyznacza [...] premię za nieuczciwość" ${ }^{\prime \prime}$. To, że działa się na rzecz interesu społecznego, samo przez się nie świadczy o moralności działania, ponieważ nadal poruszamy się w obszarze interesowno-utylitarnym, a nie duchowo-perfekcyjnym. Interes społeczny nadal może być niegodziwy. Społeczeństwo może w swej interesowności być złe i psuć poszczególnych ludzi przez odwoływanie się do ich interesów, ale jest to możliwe dzięki temu, że człowiek z natury jest interesowny. Po drugie, Elzenberg stwierdza, że w naturze ludzkiej jest „tajemnicza właściwość”, która sprawia, że człowiek, będąc członkiem większej grupy społecznej, „wypiera się dobra w sobie, jakby się go wstydził albo jakby się obawiał, że przez jego ujawnienie zerwie więzi łączące go ze społeczeństwem" ${ }^{49}$. Pesymizm historiozoficzny ma za swój przedmiot dzieje ludzkie oraz grupy ludzkie w ujęciu diachronicznym, dlatego uwagi odnoszące się w niniejszym akapicie do pesymizmu społecznego odnoszą się również do historiozoficznego.

Ponieważ państwo ma charakter wspólnotowy, to część argumentów dotyczących pesymizmu społecznego i dziejowego odnosi się również do pesymizmu państwowego. Elzenberg pisze, że pomysł uszlachetniania rodzaju ludzkiego przez wojny okazał się jałowy: ,tylko przy innym sposobie wojowania, innych państwach

\footnotetext{
45 Ibidem, s. 331-332 (18 X 1942)

46 Lekcja niepewna.

47 H. Elzenberg, Pesymistyczny pogląd na nature ludzka, [w:] MHE III-181-41, k. 12.

48 H. Elzenberg, O ascetycznym podłożu wszelkiej kultury, k. 10.

49 H. Elzenberg, Pesymistyczny poglad na naturę ludzka, k. 13.
} 
i innych ludziach [wyr. - A.P.] mogłaby ta konstrukcja sens swój zachować" Masowa heroizacja życia dzięki wojnie nie jest możliwa (między innymi) właśnie przez naturę ludzką i jej skłonności.

Co istotne, autor Prób kontaktu po odrzuceniu swej dawniejszej koncepcji roli państw i wojen stwierdza, że ,[w]zniesienie się ponad życie przez bohaterstwo masowe musiało ustąpić wzniesieniu się przez jednostkowe lub co najwyżej bohaterstwo małych grup obranych, zwłaszcza zaś temu, co z nim od początku konkurowało i co w mojej postawie później zwyciężyło wyraźnie: wzniesieniu się przez ascezę ${ }^{\text {"51. }}$

\section{Przezwyciężanie pesymizmu i asceza}

Z uwagi na pochodny charakter wartości ujemnej zło właściwe naturze ludzkiej nie jest absolutne. Człowiek jest taki, jaki powinien nie być, ponieważ nie aspiruje do realizacji wartości perfekcyjnej. Racją złej woli jest ukształtowanie natury ludzkiej, w której biologiczny wymiar jest silniejszy i powoduje, iż człowiek zainteresowany jest $\mathrm{w}$ pierwszym rzędzie wartościami w znaczeniu utylitarnym, nie zaś perfekcyjnym. Nie nienawiść do ducha jest przesłanką pesymizmu względem człowieka, lecz tendencja natury ludzkiej do jednostronnego interesowania się wartościami właściwymi sferze biologicznej. „»Chcieć żyć«, »chcieć mieć przyjemność«, »chcieć tego lub owego doznać« — to wszystko nie jest źle. Ale źle jest wyłącznie chcieć żyć, albo wyłącznie chcieć przyjemności, albo wyłącznie chcieć doznawać" ${ }^{\prime 52}$.

W takim razie przezwyciężenie pesymizmu polegałoby na przezwyciężeniu ,ludzkiej natury w sobie" przez ducha, z czego w szczególności wynika postulat ascezy. Rola ascezy w przezwyciężaniu pesymizmu polega na otwarciu się na wartości perfekcyjne przez istotę jednostronnie zainteresowaną wartościami w znaczeniu utylitarnym. Wedle Elzenberga człowiek z natury ma skłonność do ekspansji życiowej, ze szkodą dla moralności. „Dobrzy mogą być silni, ale nie są ekspansywni, zaborczy, natarczywi, zdobywczy. [...] niemoralność [...] idzie w parze ze skłonnością do ekspansji”53. Moralność z istoty jest raczej czynnikiem ograniczającym i hamującym, co w szczególności manifestuje się w ascezie i wyrzeczeniach.

Przezwyciężenie pesymizmu ma charakter etyczny. Jeżeli przesłanką pesymizmu antropologicznego jest zbytnie skupienie uwagi człowieka na wartościach w znaczeniu utylitarnym, to przezwyciężenia conditio humana nie można dokonać przez to, że ludziom będzie lepiej, lecz przez to, że ludzie będą lepsi.

W ten sposób ja dokonywam swej opcji: — za reformowaniem życia ludzkiego raczej od wewnątrz, od strony moralnej, niż od zewnątrz, od organizacyjnej (społecznej i ekonomicznej), — raczej metodą twórców religij niż wielkich organizatorów; — za pewną dwoistością życia ludzkiego, przy której z jednej strony zostają wielkie zjawiska dążeniowe (sfera „makrospołeczna”) — z drugiej — życie indywidualne i w małych grupach (mikrospołeczne) ${ }^{54}$.

\footnotetext{
${ }^{50}$ H. Elzenberg, Sprawy zbiorowości ludzkiej a mój system myślowy, s. 356.

51 Ibidem.

52 H. Elzenberg, Zasada aksjologii. Wartość i przeciwwartość, [w:] MHE III-181-17, k. 4.

53 H. Elzenberg, Pesymistyczny pogląd na naturę ludzka, k. 12.

54 Ibidem, k. 14
} 
Jeżeli przezwyciężanie pesymizmu ma być częściowym przezwyciężeniem natury ludzkiej przez etykę - częściowym, bo całkowita zmiana natury ludzkiej nie jest możliwa (stąd lepiej mówić o przezwyciężaniu niż o przezwyciężeniu) to etyka zdolna tego dokonać jest etyką perfekcjonistyczną. Owa etyka jest perfekcjonistyczna, po pierwsze dlatego, że centralną rolę odgrywa w niej wartość perfekcyjna, wartość swoista sferze przedmiotowo-duchowej. Po drugie, ponieważ Elzenberg optuje za reformowaniem życia „w skali mikrospołecznej”, więc przezwyciężenie natury ludzkiej powinno dokonywać się przez praktykę doskonalenia siebie samego, a więc przez perfekcjonizm etyczny. Jest to zgodne z postulatem, aby ,„przezwyciężać siebie raczej niż los«; słowa są, jak wiadomo, Kartezjusza, ale myśl jest stoicka"55.

Asceza w ramach przezwyciężania pesymizmu odgrywa centralną rolę. Asceza wprost sprzeciwia się wrodzonej ekspansji życiowej: „moralność polega w dużej mierze na powściągach [...], to wyklucza narzucającą się ekspansję" tyczny był stale obecny w etyce Elzenberga. Już w 1910 roku twierdził, że ,wszystkie Etyki zwalczają żądzę, jest to coś z pojęciem Etyki nierozwiązalnego" ${ }^{57}$. Z kolei w 1919 roku pisał, że utylitaryzm i hedonizm w jego oczach nie są etykami w ogóle ${ }^{58}$.

Kim jest według Elzenberga człowiek w kontekście przezwyciężania pesymizmu? Elzenbergowski obraz istoty ludzkiej dobrze oddają słowa Schelera, według którego człowiek jest istotą zdolną powiedzieć „nie” swoim popędom. Niemiecki myśliciel pisał, że człowiek „może mocą swego ducha zachować się zasadniczo ascetycznie, [...] człowiek jest »tym, który może powiedzieć 'nie'《 (»Neinsagenkönner «), »ascetą życiowym《, wiecznym protestantem przeciw wszelkiej nagiej rzeczywistości”59. Elzenberg z kolei pisał: „Umieć powiedzieć nie: to jest fundament zarówno charakteru człowieka jak jego pozycji śród ludzi. [...] Der Geist, der nie verneint: co za nędza!"60.

Najważniejszą wszak przesłanką za uznaniem ascetyzmu za kluczowy element etycznego przezwyciężenia pesymizmu jest okoliczność, że człowiek powinien tworzyć kulturę, a bez ascezy żadnej kultury być nie może.

\section{Asceza, człowieczeństwo ${ }^{61}$, kultura}

Człowiek jest zdolnym do samoprzezwyciężeń twórcą kultury. Ta charakterystyka odnosi się do podstawowej powinności ludzkiej. „Powołanie człowieka jest proste: budować świat przeciw światu" ${ }^{\prime 2}$. Światem, który ma być stworzony, w opozy-

${ }^{55}$ H. Elzenberg, Troska i myśl. O poczatkach mojego filozofowania, [w:] idem, Z filozofii kultury, s. 114.

56 H. Elzenberg, Pesymistyczny pogląd na nature ludzka, k. 12.

57 H. Elzenberg, Do etyki, [w:] MHE III-181-2, k.11.

58 H. Elzenberg, Personalia stoickie i ascetyczno-moralizatorskie, [w:] idem, Pisma etyczne, s. 140.

59 M. Scheler, Stanowisko człowieka w kosmosie, s. 103. W kontekście „protestowania” wobec „nagiej rzeczywistości" por. z uwagami Elzenberga dotyczącymi wolności wartościowania: H. Elzenberg, Kłopot z istnieniem, s. 432-433 (29 X 1956).

60 H. Elzenberg, Kłopot z istnieniem, s. 473 (30 VII 1960).

61 W całym niniejszym tekście pojęcie „człowieczeństwo” jest rozumiane jako pojęcie wartościujące, a nie jako aksjologicznie neutralne.

${ }^{62}$ H. Elzenberg, Kłopot z istnieniem, s. 239 (22 XII 1934). 
cji do „tego świata”63, jest świat kultury. Jeżeli kultura jest zespołem przedmiotów perfekcyjnie wartościowych ,to nie ma już mowy, by wolno nam ją było tworzyć albo nie tworzyć; tworzyć ją jest teraz, po pierwsze, naszą powinnością — ponieważ obejmuje ona tylko wartości, które stworzyć jest w naszej mocy, po drugie, naszą powinnością jedyną, ponieważ obejmuje je wszystkie" $"$. Podkreślić trzeba, że w kontekście kultury idzie o powinności całej ludzkości i że główne elementy kultury stanowią moralność i sztuka, nie jest to zatem kulturalizm immoralistyczny.

Wcześniej — w Nauce i barbarzyństwie - Elzenberg przez kulturę rozumiał „sumę rzeczy, których stworzenie jest w zakresie możności człowieka, a które są rzeczami wartościowymi” ${ }^{65}$ perfekcyjnie. Z ogółu przedmiotów perfekcyjnie wartościowych, część może być tworzona przez człowieka, pozostałe nie: pierwszy rodzaj przedmiotów stanowi kultura.

Szczegółowe rozumienie kultury zostało wyeksplikowane w rękopisie $O$ ascetycznym podłożu wszelkiej kultury. Kultura została zdefiniowana w kategoriach tworzenia, jako „tworzenie stanów rzeczy wartościowych w sensie perfekcjonistycznym, t. zn. doskonalszych, szacowniejszych, wyższych w hierarchii”’66. W kulturze wyróżnia się cztery niezbędne elementy:

a) wysiłek kulturotwórczy [...]

$\beta$ ) dorobek kulturalny; przedmioty wartościowe stworzone ${ }^{67}$

(ale to jest dopiero czynnik kultury ${ }^{68}$ )

$\gamma$ ) osiągnięcia kulturalne: zmiany na lepsze osiągnięte dzięki wysiłkowi i dorobkowi; bardziej wartościowe stany rzeczy osiągnięty przez ludzki wysiłek;

$\delta)^{69}$ to nie wystarcza: musi dojść wiedza o osiągnięciach, integracja osiągnięć w świadomość zbiorową: samowiedza kulturalna ${ }^{70}$.

Samowiedza kulturalna ,jjest zbiorem poprawnych sądów o wartości i opiera się na sądach o wartości"'71. Według Elzenberga głównym czynnikiem naruszającym obiektywność sądów o wartości jest interesowność i autocentryzm. Często oceniamy rzeczy jako dobre same w sobie dlatego, że są dobre dla nas (na przykład opłacalne). Elzenberg określa poznawczo wiarygodny sąd o wartości pewnego przedmiotu jako sąd zdeterminowany (resp. wyznaczony) przez naturę danego przedmiotu. A zatem „można powiedzieć, że konsekwencje sceptyczne ma wszelki pogląd, według którego sąd jest zdeterminowany przez coś innego niż przez naturę przedmiotu"72.

63 Pojęcie „tego świata” odnosi się do Pisma Świętego, w szczególności do Ewangelii św. Jana. H. Elzenberg wielokrotnie nawiązuje do zawartego w niej ascetycznego motywu świata — zob. ibidem, s. 322 (10 VIII 1942), s. 393 (16 XI 1951), s. 473 (29 VII 1960) oraz por. z 1 J 5, 19 i J 15, 18-19.

64 H. Elzenberg, Nauka i barbarzyństwo, [w:] idem, Pisma aksjologiczne, s. 355.

65 Ibidem, s. 354.

${ }^{66}$ H. Elzenberg, O ascetycznym podłożu wszelkiej kultury, k. 2.

67 Dopisek na marginesie: ,„ dobra kulturalne«".

68 Lekcja niepewna.

${ }^{69}$ Dopisek na marginesie: ,przykład z »inteligencją《".

70 H. Elzenberg, O ascetycznym podłożu wszelkiej kultury, k. 3. Jako piąty, ale nie niezbędny, element kultury Elzenberg wskazywał „program kulturalny: pewien, już w punkcie wyjścia, system wartościowań, którym się kierujemy w naszym wysiłku”. Ibidem, k. 10. Chodzi rzecz jasna o wysiłek kulturotwórczy.

71 Ibidem, k. 3.

72 L. Hostyński, Układacz tablic wartości, Lublin 1999, s. 78. 
Główne źródła nieprawidłowych determinacji stanowią: rzutowanie interesów, sympatii, antypatii, potrzeb, życzeń, namiętności, pożądań i uprzedzeń podmiotu formułującego sąd o wartości na przedmiot sądzenia. Gdyby każdy sąd był zdeterminowany nie przez naturę sądzonego przedmiotu, konsekwencje byłyby sceptyczne, ponieważ owe czynniki uboczne - same przez się — nie pełnią funkcji poznawczych.

Polski aksjolog sformułował tezę: „warunkiem samowiedzy kulturalnej, a więc i pełni kultury (w sensie perfekcjonistycznym) jest pewna doza ascetyzmu w społeczeństwie, które kulturę tworzy"73. Bez ascezy nie może być kultury, ponieważ część kultury stanowi samowiedza kulturowa, która jest zbiorem poprawnych sądów o wartości. Z kolei „niema poprawnych sądów o wartości bez samoprzezwyciężeń w samym akcie sądzenia" ${ }^{\text {"74 }}$ oraz bez pewnej ascezy przed sformułowaniem sądów. Bez samoprzezwyciężania istnieje duże ryzyko, że będziemy wartościować w ramach perspektywy podmiotowej. Dzięki ascezie można oceniać obiektywnie, ponieważ w ascezie duch przezwycięża to, co biologiczne, a ogląd sfery duchowej ma charakter przedmiotowy, niezrelatywizowany do podmiotu. W ten sposób asceza służy kontrolowaniu warunków, w których ocena zostaje formułowana. Elzenberg podkreśla, że nie idzie o samą ,zwykłą” bezstronność, ponieważ samoprzezwyciężenie dokonywane w akcie sądzenia spełnia warunki definicyjne ascezy. Uleganie sympatiom, antypatiom, interesom i żądzom stanowi element natury ludzkiej, spełniony jest więc pierwszy warunek definicyjny ascezy. Spełniony jest również drugi warunek, ponieważ samoprzezwyciężanie w akcie sądzenia jest przezwyciężaniem silniejszej, biologicznej części natury ludzkiej. Także trzeci warunek zostaje zrealizowany, ponieważ samoprzezwyciężanie w akcie sądzenia zarówno zachowuje bardziej indywidualny charakter (wedle Elzenberga wartości poznajemy za pomocą intuicji, a poznanie intuicyjne jest zawsze jednostkowe - nie ma intuicji zbiorowych, społecznych) oraz posiada bardziej „idealne” cele, gdyż omawiane samoprzezwyciążanie dotyczy właśnie wartości perfekcyjnych. Autopedagogiczny watek ascezy zostanie poruszony w odpowiednim miejscu.

Nigdy nie możemy być pewni, czy, formułując ocenę, wyłamaliśmy się spod wpływu determinacji ubocznych ${ }^{75}$. Czy zatem wysiłki na rzecz tworzenia kultury mają sens, skoro nasze dzieło może nie być częścią kultury? Czy nie należałoby powstrzymać się od prób tworzenia kultury, skoro nie mamy pewności sukcesu starań? W odpowiedzi na taki zarzut Elzenberg proponuje pewien „zakład”, który w swej formie podobny jest do tak zwanego zakładu Pascala: nawet jeśli nie wiemy, czy to, co stworzymy, będzie autentyczną kulturą, należy podjać ryzyko jej tworzenia, bo przy naszym działaniu są jakieś szanse zaistnienia kultury, a uchylanie się od tego ryzyka oznacza pewność, że kultura nie powstanie ${ }^{76}$.

Asceza jest nie tylko warunkiem kultury, jest także częścią kultury. Jeżeli dana asceza jest taka, jaka być powinna, to jest również częścią kultury, gdyż kultura obejmuje wszystkie przedmioty perfekcyjnie wartościowe będące wytworem człowieka (w tym uczynki).

\footnotetext{
${ }^{73}$ H. Elzenberg, O ascetycznym podłożu wszelkiej kultury, k. 3.

74 Ibidem, k. 4.

75 A. Nogal-Poniewska, Watki antropologiczne w filozofii Henryka Elzenberga, s. 269.

76 Zob. H. Elzenberg, Nauka i barbarzyństwo, s. 355-356.
} 
Najistotniejszym rezultatem tworzenia kultury jest to, że kultura nadaje człowiekowi człowieczeństwo. To pozwala zdefiniować Elzenbergowskie pojęcie człowieczeństwa jako cechę lub zespół cech, którą człowiek osiąga wtedy, gdy realizuje wartości duchowe oraz gdy oddaje się ich realizacji. Logicznie równoważna definicja brzmi: człowieczeństwo jest cechą lub zespołem cech, które człowiek nabywa przez tworzenie kultury.

Pojęcia człowieczeństwa i natury ludzkiej nie są tożsame, a nawet są pod pewnymi względami przeciwstawne. W Kłopocie z istnieniem czytamy:

Za przykład weźmy chociażby ten wyraz człowieczeństwo (użyty nie w sensie przynależności do gatunku homo; tylko w intencji pochwalnej i wyróżniającej). [...] Nie może znaczyć „szlachectwo" ani „mądrość”, choć pewna mądrość jest, w moim odczuciu, jego składnikiem, a ono samo jest, owszem, czymś, w czym dopatruję się szlachectwa. Ma też swoje całkiem uchwytne przeciwieństwa: ,zwierzęcość", „bestialstwo"77.

Wyraz „człowieczeństwo” ma charakter wartościujący, a „natura ludzka” — opisowy. Skoro posiadanie człowieczeństwa i przynależność do gatunku homo nie są tym samym, a przynależność do gatunku homo jest równoznaczna z posiadaniem natury ludzkiej, wynika stąd, że posiadanie człowieczeństwa i posiadanie ludzkiej natury to różne rzeczy. Posiadanie człowieczeństwa jest zależne od posiadania natury ludzkiej, ponieważ tylko członek gatunku homo może mieć człowieczeństwo, posiadanie natury ludzkiej nie pociąga jednak za sobą posiadania człowieczeństwa. Skoro natura ludzka jest wrodzona każdemu człowiekowi i każdy przedstawiciel gatunku homo ma ludzką naturę, to człowieczeństwo we wskazanym sensie nie jest czymś, co jest wszystkim ludziom wrodzone — jedni bowiem owo człowieczeństwo posiadają, a drudzy nie (na co wskazywać może między innymi okoliczność, że tylko istota należąca do gatunku homo może być mądra, ale faktem jest, że niektórzy ludzie są całkowicie pozbawieni mądrości). Jeżeli człowieczeństwo nie jest wrodzone, tedy jest nabyte.

Można stąd wyprowadzić inne cechy człowieczeństwa. Natura ludzka przysługuje każdemu człowiekowi w równym stopniu. Albo ktoś przynależy do gatunku homo i ma naturę ludzką, albo nie. Człowieczeństwo natomiast może występować u jednego człowieka w większym stopniu, a u drugiego w mniejszym, analogicznie do mądrości i szlachetności, gdyż jedni ludzie są mądrzejsi i szlachetniejsi od drugich. Jakkolwiek filozof nie przeprowadził analizy człowieczeństwa przez pryzmat własnych kategorii aksjologicznych, faktem jest, że wiązał posiadanie człowieczeństwa z posiadaniem cech wartościotwórczych, jak szlachetność lub mądrość. Można postawić hipotezę, że samo człowieczeństwo stanowi cechę wartościotwórczą sui generis, zespół takich cech lub pewną całość, której części stanowią (między innymi) cechy wartościotwórcze. Przeciwieństwem człowieczeństwa jest zwierzęcość i bestialstwo. Bestialstwo oznacza szczególnie ostre zwyrodnienie niegodne istoty ludzkiej. Skoro bestialstwo jest kojarzone ze zezwierzęceniem, to przypisując komuś bestialstwo, sugeruje się, że ten ktoś jest bardziej podobny do zwierzęcia niż inni ludzie oraz że jest bardziej podobny do zwierzęcia niż powinien (w tym znaczeniu słowa „zwierzę", w którym — jak pisał M. Scheler — człowiek nie jest

77 H. Elzenberg, Kłopot z istnieniem, s. 494 (1 I 1962). 
zwierzęciem, lecz czymś przekraczającym porządek czysto animalny ${ }^{78}$ ). Zwierzęta, wedle Elzenberga, sa istotami czysto biologicznymi, a człowiek jest jedyną istotą mającą ducha. Istota posiadająca człowieczeństwo posiada jakoś rozwiniętego ducha. W takim razie, skoro bestialstwo wzmacnia w człowieku stronę biologiczną, a człowieczeństwo przeciwstawia się bestialstwu, to człowieczeństwo nie tylko akcentuje duchową stronę natury ludzkiej, ale także wskazuje, że ci, którzy człowieczeństwo mają (resp. mają je w stopniu wysokim), posiadają (resp. posiadają w znaczącym stopniu) cechy specyficznie ludzkie (to jest duchowe), cechy właściwe tylko i wyłącznie człowiekowi.

To pozwala sformułować kluczową tezę Elzenbergowskiej antropologii filozoficznej: człowiek, który posiada człowieczeństwo (resp. posiada je w wysokim stopniu) i je realizuje, jest człowiekiem „bardziej” niż ten, kto człowieczeństwa nie ma (resp. ma go mniej). Osoba dysponująca człowieczeństwem jest nie tylko bardziej wartościowa, ale również bardziej ludzka niż ktoś, kto człowieczeństwa jest pozbawiony, bowiem ktoś posiadający człowieczeństwo przejawia więcej rysów specyficznie ludzkich, które mogac przysługiwać wyłacznie przedstawicielowi gatunku homo. Istota o ludzkiej naturze ex definitione posiada cechy ludzkie, ale skoro posiadanie człowieczeństwa jest pewnym ,naddatkiem” względem natury ludzkiej, to człowiek posiadający człowieczeństwo ma więcej cech specyficznych dla człowieka niż ten, kto posiada tylko ludzką naturę. Człowiek realizujący wartości to człowiek tworzący kulturę, a istota tworząca kulturę jest człowiekiem par excellence. Człowiek realizujący człowieczeństwo jest taki, jaki powinien być.

Jeżeli kultura (łac. humanitas) pełni funkcję uczłowieczającą i sprawia, że człowiek staje się bardziej człowiekiem, to Elzenbergowską koncepcję kultury można określić jako paideutyczną. Dopiero uznając paideutyczny charakter kultury można zrozumieć fakt, że autor Prób kontaktu wiązał ascezę z (auto)pedagogiką i perfekcjonistycznym samodoskonaleniem. Termin paideia jest tu rozumiany szeroko, za Wernerem Jaegerem, w sensie ,wychowania w człowieku jego właściwego charakteru, prawdziwego człowieczeństwa"79. Na paideutyczne znaczenie kultury wskazuje również okoliczność, że dla polskiego myśliciela w pojęciu kultury na czoło wysuwał się normatywny aspekt kultury. Jeager czynił rozróżnienie „pomiędzy kulturą jako pojęciem czysto antropologicznym, które oznacza tryb życia albo charakter jakiegoś narodu, a kulturą pojętą jako ideał doskonałości ludzkiej"80. Elzenbergowi był bliższy drugi sposób rozumienia kultury.

O tym, że człowiek będący sługą wartości oraz twórcą kultury jest człowiekiem par excellence, Elzenberg pisze w Kłopocie z istnieniem: „Jaki jest cel wykształcenia klasycznego? Dać człowiekowi kulturę? Raczej: dać kulturze człowieka"»1. Ten cytat warto zestawić z wypowiedziami Elzenberga, w których mówił o technicznie sprawnych „gorylach”82. „Wykształcenie” w powyższym cytacie nie oznacza wyłącz-

78 M. Scheler, Stanowisko człowieka w kosmosie, s. 48.

79 W. Jaeger, Paideia. Formowanie człowieka greckiego, tłum. M. Plezia, H. Bednarek, Warszawa 2001 , s. 38.

80 Ibidem, s. 50, przyp. 5.

81 H. Elzenberg, Kłopot z istnieniem, s. 60 (23 II 1911).

82 Zob. ibidem, s. 252 (31 VIII 1936); także ibidem, s. 238 (1 I 1936). 
nie oczytania i posiadania wiedzy encyklopedycznej, ponieważ elementem kształcenia klasycznego było formowanie duszy ludzkiej, zwłaszcza wrażliwości i smaku, aby były skierowane ku temu, co wartościowe. Barbarzyńcą nie jest ktoś, kto nie zna imienia autora Prometeusza w okowach, lecz ten, kto (parafrazując Arystypa z Cyreny), siedzi w teatrze jak kamień na kamieniu. Samą twórczość kulturalną Elzenberg rozumiał szeroko, jako „wprowadzanie w byt (nadanie istnienia) czegoś nowego"83, a przykłady, jakie podawał w zapiskach zatytułowanych Etyka Gandhiego jako przykład twórczości etycznej w dobie obecnej, ${ }^{84}$, wskazuja, że twórczość nie polega tylko na wytwarzaniu dzieł i że twórczość może polegać także na przekształcaniu nas samych.

\section{Podsumowanie i wnioski}

Filozofię Elzenberga można rozpatrywać jako próbę przezwyciężania pesymizmu. Główną rolę w pesymizmie autora Prób kontaktu odgrywa pesymizm antropologiczny, będący ujemną oceną człowieka jako takiego. Przezwyciężanie pesymizmu jest przede wszystkim przezwyciężaniem pesymizmu względem natury ludzkiej. W takim razie przezwyciężanie pesymizmu polega na przezwyciężaniu natury ludzkiej, przy czym charakter owego przezwyciężania jest etyczny, a asceza jest głównym środkiem przekształcania natury ludzkiej.

Asceza pełni fundamentalną rolę w Elzenbergowskiej antropologii filozoficznej, a związek człowieka z ascezą jest tak silny, że toruński filozof charakteryzował człowieka jako istotę, która może i powinna przezwyciężać siebie samą. Autor Kłopotu z istnieniem definiuje ascezę jako systematyczną, celową praktykę samoprzezwyciężania, która jest zorientowana na wartości perfekcyjne, ma większy stopień trudności niż zwykła samodyscyplina moralna, nie polega na dostosowywaniu się do społeczeństwa i ma cele autopedagogiczne. Związek ascezy z przezwyciężaniem pesymizmu jest fundamentalny, ponieważ zło natury ludzkiej polega na tym, że człowiek z natury nie chce tego, co perfekcyjnie wartościowe, człowiek jako taki chce siebie, jest interesowny, ma naturalną tendencję do relatywizowania wszelkiego dobra do siebie lub innych podmiotów. Asceza z kolei, ograniczając interesowność w człowieku, otwiera przed nim perspektywę przedmiotowo-duchową, swoistą dla obcowania z wartościami perfekcyjnymi.

Dokonując samoprzezwyciężeń, duchowa strona natury ludzkiej wyrywa się spod przewagi czynnika biologicznego. Pod wpływem ascezy człowiek staje się (w pełni/ bardziej) człowiekiem, ponieważ asceza rozwija ducha, a duch jest specyficzny wyłącznie dla rodzaju ludzkiego. Elzenberg opisuje ów rozwój jako nabywanie człowieczeństwa przez człowieka. Jeżeli za Elzenbergiem zdefiniuje się kulturę jako ogół stworzonych przez człowieka przedmiotów perfekcyjnie wartościowych, to nabywanie człowieczeństwa jest równoważne z realizowaniem wartości perfekcyjnych oraz tworzeniem kultury. A zatem tworzenie kultury pokrywa się z procesem uczłowie-

${ }^{83}$ H. Elzenberg, Etyka Gandhiego jako przykład twórczości etycznej w dobie obecnej, [w:] MHE 133, k. 2 .

${ }^{84}$ Między innymi kultywacja cnót lub kształtowanie w ludziach chęci samodoskonalenia. 
czania się człowieka, co znaczy, że istota ludzka przez kulturę realizuje pełnię swojej natury i właściwe jej potencje. To pozwala określić Elzenbergowską koncepcję kultury jako paideutyczną (w sensie Jaegera).

Zebrane wyniki pozwalają na dalsze badania nad Elzenbergowską filozofią człowieka, która jest szczególnie interesująca z tego powodu, że autor Prób kontaktu jest głównie znany jako aksjolog. W szczególności zebrane wyniki badań umożliwiają wgląd w obustronne relacje zachodzace między Elzenbergowską filozofiac wartości a antropologią filozoficzną, a zwłaszcza wgląd w antropologiczne założenia stojące za Elzenbergowską etyką. Ponadto wyniki badawcze mogą służyć za podstawę refleksji komparatystycznej. Interesujące byłoby systematyczne zbadanie podobieństw i różnic między Elzenbergowską filozofią człowieka a wynikami refleksji niemieckich twórców tak zwanej nowej antropologii filozoficznej, a w szczególności Schelera, wedle którego człowiek to jedyna istota duchowa zdolna zanegować instynkty i powiedzieć życiu „nie”.

\section{Bibliografia}

Elzenberg H., Do etyki, [w:] Materiały Henryka Elzenberga, Archiwum PAN, sygn. III-181 , teczka 2.

Elzenberg H., Etyka Gandhiego jako przykład twórczości etycznej w dobie obecnej, [w:] Materiały Henryka Elzenberga, Archiwum PAN, sygn. III-181, teczka 133.

Elzenberg H., Etyka wyrzeczenia, [w:] idem, Pisma etyczne, oprac. L. Hostyński, Lublin 2001, s. 157-182.

Elzenberg H., Etyka wyrzeczenia. Czym jest i jak bywa uzasadniania?, [w:] idem, Pisma etyczne, oprac. L. Hostyński, Lublin 2001, s. 3-21.

Elzenberg H., Kłopot z istnieniem. Aforyzmy w porzadku czasu, Toruń 2002.

Elzenberg H., Nauka i barbarzyństwo, [w:] idem, Pisma aksjologiczne, oprac. L. Hostyński, A. Lorczyk, A. Nogal, Lublin 2002, s. 353-362.

Elzenberg H., O ascetycznym podłożu wszelkiej kultury, [w:] Materiały Henryka Elzenberga, Archiwum PAN, sygn. III-181, teczka 61.

Elzenberg H., O rzeczywistym wodzostwie (w zwiazku z dyskusja o Gandhim) [w Materiaty Henryka Elzenberga, Archiwum PAN, sygn. III-181, teczka 56.

Elzenberg H., Personalia stoickie $i$ ascetyczno-moralizatorskie, [w:] idem, Pisma etyczne, oprac. L. Hostyński, Lublin 2001, s. 115-155.

Elzenberg H., Pesymistyczny poglad na naturę ludzka, [w:] Materiały Henryka Elzenberga, Archiwum PAN, sygn. III-181, teczka 41.

Elzenberg H., Pojęcie wartości i powinności. Tekst żemłosławski, [w:] idem, Pisma aksjologiczne, oprac. L. Hostyński, A. Lorczyk, A. Nogal, Lublin 2002, s. 123-168.

Elzenberg H., Sprawy zbiorowości ludzkiej a mój system myślowy, [w:] idem, Z filozofii kultury, Kraków 1991, s. 354-368.

Elzenberg H., Troska i myśl. O początkach mojego filozofowania, [w:] idem, Z filozofii kultury, Kraków 1991, s. 110-117.

Elzenberg H., Walka moralistów z żądza, [w:] Materiały Henryka Elzenberga, Archiwum PAN, sygn. III-181, teczka 36. 
Elzenberg H., Wartość ujemna, [w:] idem, Pisma aksjologiczne, oprac. L. Hostyński, A. Lorczyk, A. Nogal, Lublin 2002, s. 169-175.

Elzenberg H., Zasada aksjologii. Wartość i przeciwwartość, [w:] Materiały Henryka Elzenberga, Archiwum PAN, sygn. III-181, teczka 17.

Hostyński L., Układacz tablic wartości, Lublin 1999.

Jaeger W., Paideia. Formowanie człowieka greckiego, tłum. M. Plezia, H. Bednarek, Warszawa 2001.

Nogal-Ponikiewska A., Wattki antropologiczne w filozofii Henryka Elzenberga. Rekonstrukcja i historyczno-filozoficzna analiza porównawcza, Warszawa 1998 (nieopublikowana praca doktorska).

Scheler M., Stanowisko człowieka w kosmosie, tłum. A. Wegrzecki, [w:] idem, Pisma $z$ antropologii filozoficznej i teorii wiedzy, tłum. S. Czerniak, A. Węgrzecki, Warszawa 1987, s. $43-149$.

Schrade U., Natura ludzka a wartości, „Archiwum Historii Filozofii i Myśli Społecznej" 34 (1989), s. 71-86.

Tyl M., Pesymizm, konserwatyzm, wartości. O filozofii Henryka Elzenberga, Katowice 2001.

Wolniewicz B., Myśl Elzenberga, [w:] B. Wolniewicz, Filozofia i wartości. Rozprawy i wypowiedzi z fragmentami pism Tadeusza Kotarbińskiego, Warszawa 1993, s. 69-93. 